\title{
Non-coding RNAs and retroviruses
}

\author{
Xu Zhang ${ }^{1,2,3}$, Xiancai Ma ${ }^{1,2,3}$, Shuliang Jing ${ }^{1,2,3}$, Hui Zhang ${ }^{1,2,3^{*}}$ and Yijun Zhang ${ }^{4^{*}}$ (D)
}

\begin{abstract}
Retroviruses can cause severe diseases such as cancer and acquired immunodeficiency syndrome. A unique feature in the life cycle of retroviruses is that their RNA genome is reverse transcribed into double-stranded DNA, which then integrates into the host genome to exploit the host machinery for their benefits. The metazoan genome encodes numerous non-coding RNAs (ncRNA), which act as key regulators in essential cellular processes such as antiviral response. The development of next-generation sequencing technology has greatly accelerated the detection of ncRNAs from viruses and their hosts. ncRNAs have been shown to play important roles in the retroviral life cycle and virus-host interactions. Here, we review recent advances in ncRNA studies with special focus on those have changed our understanding of retroviruses or provided novel strategies to treat retrovirus-related diseases. Many ncRNAs such as microRNAs (miRNAs) and long non-coding RNAs (IncRNAs) are involved in the late phase of the retroviral life cycle. However, their roles in the early phase of viral replication merit further investigations.
\end{abstract}

Keywords: Non-coding RNA, Retroviruses, Viral life cycle, Virus latency, MicroRNA, Long non-coding RNA

\section{Background}

\section{The classification and life cycle of retroviruses}

Retroviruses represent a large and diverse family of enveloped RNA viruses defined by common taxonomic denominators that include structure, composition, and replicative properties [1]. A key feature of the retroviral life cycle is that the RNA genome is reverse-transcribed to double-stranded DNA, which is subsequently integrated into the host genome and turns to a provirus. The viral genes are transcribed from the integrated proviral DNA to produce proteins and genomic RNA required to assemble the progeny viral particles. Retroviruses are further subdivided into seven groups (genus) defined by their evolutionary relatedness [2]. Retroviruses in five of these groups have oncogenic potential (formerly referred to as oncoviruses), and the other two groups are lentiviruses and spumaviruses. The representative of the lentivirus family is the human immunodeficiency virus type 1 (HIV-1), the causative agent of acquired immunodeficiency syndrome (AIDS). There are over 36 million

\footnotetext{
*Correspondence: zhangh92@mail.sysu.edu.cn; yi-jun.zhang@yale.edu ${ }^{1}$ Institute of Human Virology, Zhongshan School of Medicine, Sun YatSen University, Guangzhou 510080, China

${ }^{4}$ Section of Infectious Diseases, Department of Internal Medicine, Yale University School of Medicine, New Haven, CT 06520, USA

Full list of author information is available at the end of the article
}

people living with HIV-1 worldwide, with approximately 2.1 million new infections being reported in 2015. To date, there is no cure for AIDS because of the existence of the HIV reservoir. The latent reservoir is a group of HIV-infected cells (mainly resting $\mathrm{CD} 4^{+} \mathrm{T}$ cells) that do not actively produce new HIV-1, but could produce virus again upon stimulation [3].

The life cycle of retroviruses can be simply divided into the early and late phases. The early phase refers to the steps from cell binding to integration of the viral cDNA in the host genome, whereas the late phase begins with the expression of viral genes and is followed by the assembly, release, and maturation of progeny virions [4]. For HIV1 , the lifecycle can be briefly divided into seven steps: (1) attachment and binding, (2) fusion and uncoating, (3) reverse transcription, (4) integration, (5) transcription, (6) assembly, and (7) budding (Fig. 1A-G). Steps 1-4 represent the early phase, and steps 5-7 represent the late phase of a typical retrovirus life cycle. In addition, there is a special state of the retrovirus life cycle called latent infection. Under such conditions, the proviral DNA is transcriptionally inactive without producing infectious viral particles. As the host $\mathrm{CD} 4^{+} \mathrm{T}$ cells are activated, the phase of latent HIV infection can be reversed to productive infection $[3,5]$. Numerous host factors are involved 


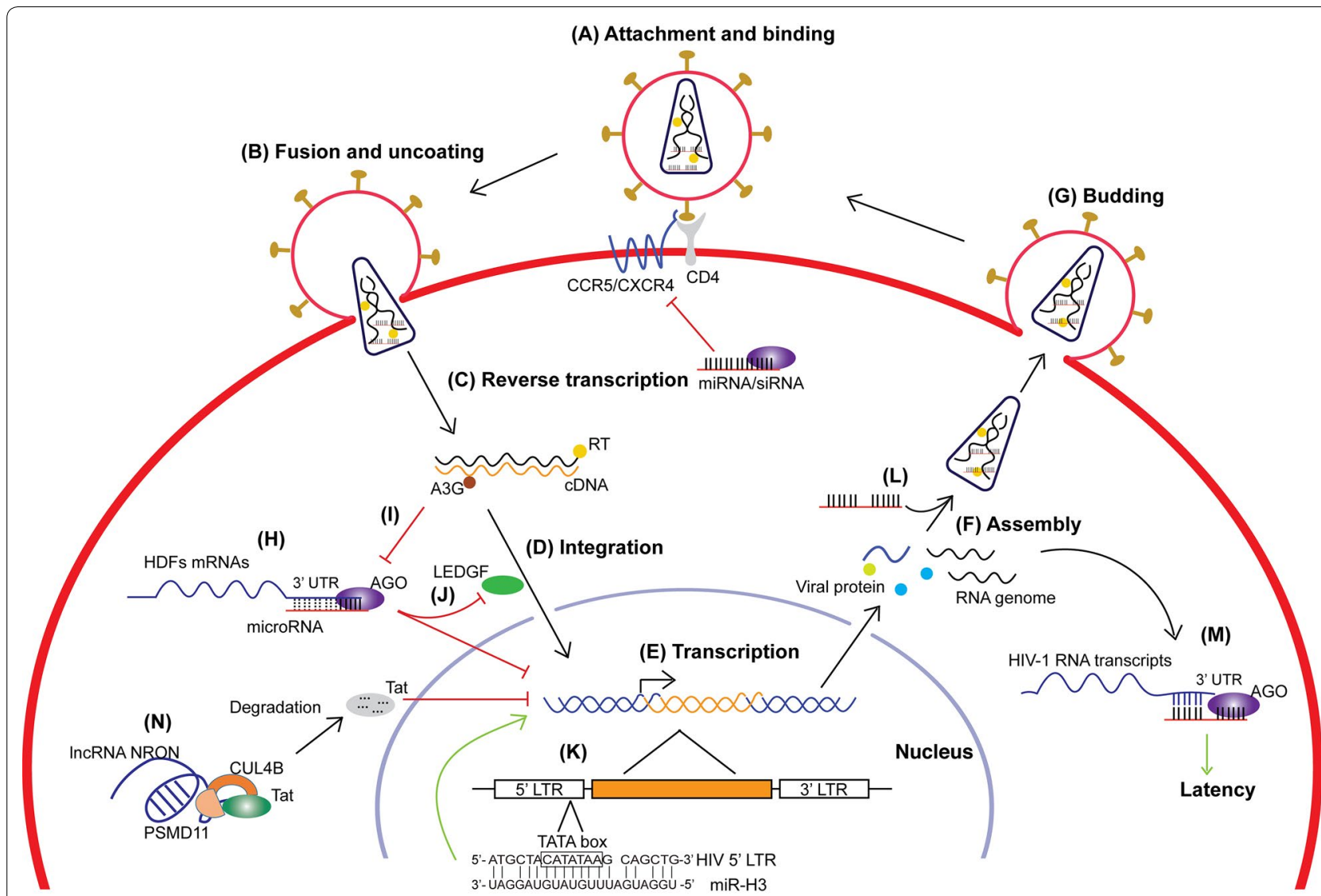

Fig. 1 Non-coding RNAs and HIV-1 life cycle. The life cycle of HIV-1 includes: attachment and binding, fusion and uncoating, reverse transcription, integration, transcription, assembly, budding and latency. The roles of representative microRNAs and long non-coding RNAs in HIV-1 life cycle are shown. RT reverse transcriptase; A3G APOBEC3G; AGO Argonaute protein; LEDGF lens epithelium-derived growth factor or p75; HDFs host dependency factors; miRNA microRNA; siRNA small interfering RNA

in the life cycle of retroviruses, being either indispensable or restrictive [6].

Virology and RNA biology have reciprocally influenced each other for decades [7]. The capping of eukaryotic mRNA was first discovered in reovirus and vaccinia virus [8]. Splicing and then alternative splicing were first demonstrated by analysis of adenoviral transcription $[9,10]$. Analysis of viral systems, in particular picornaviruses, led to the first description of an internal ribosome entry site (IRES) [7]. Retroviruses have also played an important role in understanding the export of mRNAs from the nucleus to the cytoplasm. For host transcripts, only fully spliced mRNAs can be exported to the cytoplasm. However, for some retroviruses such as HIV-1, both spliced and unspliced transcripts need to be exported to the cytoplasm to produce viral proteins or serve as genomic RNA. HIV-1 encodes a special protein called Rev that exports its unspliced mRNA transcripts containing the Rev Response Element (RRE) to the cytoplasm [11]. To accomplish this function, Rev harbors a nuclear export signal (NES), which was the first NES described, and still remains the prototype of the most common class of NESs [12]. Compatible with such significant progress in virus research, the recent advances in non-coding RNA (ncRNA) research have greatly extended our understanding of viruses.

\section{The classification and functions of non-coding RNAs}

Genomic studies have demonstrated that only two percent of the human genome codes for proteins, whereas the majority codes for numerous non-protein coding RNAs (or non-coding RNA, ncRNA) [13]. Based on their function, non-coding RNAs can be divided into two major groups: (1) housekeeping non-coding RNA such as ribosomal RNA (rRNA), transfer RNA (tRNA), small nuclear RNA (snRNA), and small nucleolar RNA (snoRNA); and (2) regulatory non-coding RNA such as microRNA (miRNA), long non-coding RNA (lncRNA), and piwi-interacting RNA (piRNA) [14]. The housekeeping non-coding RNAs are mainly involved in the 
basic biological processes in cells, such as snRNA for pre-mRNA splicing, rRNA and tRNA for mRNA translation, snoRNA for rRNA methylation/pseudouridylation. However, the regulatory non-coding RNAs exert more diverse and sophisticated functions such as miRNA for regulating gene transcription and translation, lncRNA for modifying epigenetic signatures of chromatin, and piRNA for silencing transposons [14]. Unlike housekeeping ncRNAs, the expression of regulatory ncRNAs is usually tissue-specific and their regulation is gene-specific, which is mostly enabled by sequence-specific interactions between the ncRNA and its target(s) [15]. During viral infection, the regulatory ncRNAs exhibit more profound changes in expression and sophisticated functions compared to the housekeeping ncRNAs [16].

\section{RNA interference and microRNA}

RNA interference (RNAi) was proposed to initially evolve in plants and invertebrates as a native immune response against viruses [17]. In plant and invertebrate cells, the infection of all RNA viruses, except retroviruses, leads to the generation of perfectly base-paired long double stranded RNAs (dsRNA), which are cleaved by the exonuclease Dicer into $\sim 22$ bp short dsRNAs named small interfering RNA (siRNA) [17]. This is also true for some DNA viruses. One strand of the siRNA duplex is loaded into the RNA-induced silencing complex (RISC), where it guides RISC to mRNA containing complementary sequence [18]. Since these virus-derived siRNAs are fully complementary to viral mRNAs, the RISC binding guided by these siRNAs will silence their cognate viral RNAs and inhibit virus replication. In plants and nematodes, this antiviral response can be further amplified by generating a secondary wave of siRNAs through a mechanism involving RNA-dependent RNA polymerases (RdRPs) $[19,20]$. In mammalian cells, RNAi mediated by siRNA is no longer a major form of the antiviral response. Instead, interferon (IFN) response and it-induced systematic antiviral state play a key role (reviewed in Ref. [21]). However, the RNAi mechanism was retained to generate endogenous microRNA (miRNA) and regulate the expression of a significant amount of genes. MicroRNAs represent an important class of regulators in many crucial biological processes in animals, plants, fungi, and viruses [22, 23]. In the nucleus, primary miRNAs (pri-miRNAs) are transcribed and processed by Drosha and its cofactor DGCR8 (also known as Pasha, located in the DiGeorge syndrome chromosomal region) to generate precursor miRNAs (pre-miRNAs) [24], which are then exported to the cytoplasm [25] and further sliced by Dicer to generate $\sim 22$ nt mature miRNAs [26]. Like siRNAs, one strand of mature miRNAs is bound by Argonaute (AGO) proteins and loaded into the RISC [27] for guiding the RISC to the $3^{\prime}$ UTR of mRNAs to suppress translation or induce degradation. Unlike siRNAs, which fully complement to their target mRNA, most miRNAs bind to the target mRNA mainly through the "seed sequence", residues $2-8$ of the guide miRNAs (Fig. $1 \mathrm{H}$ ). The regulatory target sequences of miRNA have been extended to the $5^{\prime}$ UTR [28] and the coding region [29] of mRNAs to suppress translation. Moreover, miRNAs could switch from suppressor to activator of translation by targeting the $5^{\prime}$ UTR [30] or $3^{\prime}$ UTR [31] of certain mRNAs. In addition to regulating mRNA translation in the cytoplasm, mounting evidence reveals that the small RNA-Ago pathway can also positively regulate gene expression by targeting gene promoters in the nucleus, a phenomenon termed as RNA activation (RNAa), which is evolutionarily conserved from Caenorhabditis elegans to human [32-35].

\section{Long non-coding RNAs}

The ENCODE (The Encyclopedia of DNA Elements) Project led to the discovery of a large proportion of long transcripts from the human genome that do not code proteins (long non-coding RNAs, lncRNAs) [36]. lncRNAs can be operationally defined as RNA transcripts larger than $200 \mathrm{bp}$ without any coding potential [37]. They appear in the genome in three major forms: antisense lncRNAs, intronic lncRNAs, and intergenic lncRNAs (also termed large intervening noncoding RNAs or lincRNAs). One of the major functions of lncRNA is to regulate gene activity through interactions with chromatin, especially to suppress gene expression. For instance, gene expression on the X-chromosome can be inactivated by the lncRNA Xsit [38]. Although the mechanisms of IncRNA-mediated gene regulation are diverse, three main mechanistic themes have been drawn from dozens of examples (see review by Rinn and Chang [37]). These include decoys, scaffolds, and guides. Notably, when an lncRNA guide protein complex to the target site on chromatin, how does the lncRNA recognize and interact with the target DNA is still unclear. In addition to using DNA-binding protein(s) as adapter, the RNADNA direct interaction through RNA:DNA hybrid or RNA:DNA:DNA triplex are also possible forms requiring further investigation [39]. Increasing attention has been given to lncRNAs due to their strong connection with the development of various diseases, especially cancers. The elevated expression of the lncRNA Hox transcript antisense intergenic RNA (HOTAIR) has been observed in human breast, colon, and liver cancers, and facilitates cancer metastasis in vivo [40-42]. Extensive studies on the role of lncRNA in cancers may provide useful insights for the study of lncRNAs in the retrovirus system.

In this review, we discuss recent advances in the study of non-coding RNAs that play important roles in the life 
cycle of retroviruses, with special focus on miRNAs and lncRNAs (Tables 1, 2). Moreover, the treatment of retrovirus-related diseases can also benefit from the study of non-coding RNAs.

\section{Non-coding RNAs and the early phase of the retrovirus life cycle}

The early phase of retrovirus life cycle includes binding and fusion of virions to host cells, reverse transcription of viral genomic RNA into cDNA, and its integration in the host chromosome (Fig. 1A-D). During the binding and fusion steps, viral Env proteins play a leading role. The HIV-1 Env trimer first binds to the cell surface CD4 receptor and induces conformational changes that allows binding to the CCR5 or CXCR4 co-receptor, which mediates the fusion of viral and cell membranes. The study on how non-coding RNAs are involved in these steps is missing. In general, RNA is quite unstable in the extracellular environment and ready to be degraded by RNase. However, several reports showed that some ncRNAs, e.g. miRNAs or lncRNAs, are circulating in the blood, which can serve as biomarkers of various diseases [43, 44]. The improved stability of these ncRNAs could be due to their small size or special secondary structures [37]. An implication from the existence of these extracellular RNAs is that the non-coding RNAs can be involved in the early steps of retroviral infection, such as the binding and fusion of virions to the host cells. A possibility

Table 1 Retroviral and host microRNA

\begin{tabular}{|c|c|c|c|c|c|c|}
\hline & Virus & Name & Viral target(s) & Cellular target(s) & Function & References \\
\hline \multirow[t]{7}{*}{ Viral microRNA } & HIV-1 & miR-H3 & HIV-1 5' LTR TATA box & & $\begin{array}{l}\text { Enhance HIV-1 5' LTR tran- } \\
\text { scription }\end{array}$ & {$[77]$} \\
\hline & & $\begin{array}{l}\text { TAR-derived } \\
\text { miRNA }\end{array}$ & & $\begin{array}{l}\text { ERCC1, IER3, Caspase 8, Aio- } \\
\text { los, Ikaros, Nucleophos- } \\
\text { min (NPM)/B23 }\end{array}$ & $\begin{array}{l}\text { Protect the infected cells } \\
\text { from apoptosis, maintain } \\
\text { balance between apopto- } \\
\text { sis and cell survival }\end{array}$ & {$[70,71,75,76]$} \\
\hline & & miR-N367 & Nef & & Block HIV-1 Nef expression & {$[72]$} \\
\hline & & vmiRNA\#1-5 & & Predicted & Unknown & {$[68]$} \\
\hline & BLV & B1-5 & & Bovine HBP1, PXDN & $\begin{array}{l}\text { Mimic host miR-29, tumo- } \\
\text { rigenesis }\end{array}$ & {$[66]$} \\
\hline & BFV & $\begin{array}{l}\text { miR-BF2-5p } \\
\text { miR-BF1-5p } \\
\text { miR-BF1-3p }\end{array}$ & & & Unknown & {$[85]$} \\
\hline & ALV-J & $\mathrm{E}(\mathrm{XSR}) \mathrm{miRNA}$ & & & $\begin{array}{l}\text { Unknown, possible roles } \\
\text { in myeloid leukosis associ- } \\
\text { ated with ALV-J }\end{array}$ & {$[86]$} \\
\hline \multirow[t]{8}{*}{ Host microRNA } & & $\begin{array}{l}\text { miR-29a } \\
\text { miR-29b } \\
\text { miR-149 } \\
\text { miR-378 } \\
\text { miR-324-5p }\end{array}$ & $\begin{array}{l}\text { HIV-1 Nef, Vpr, Env, Vif } \\
\text { transcripts }\end{array}$ & & $\begin{array}{l}\text { Downregulate the expres- } \\
\text { sion of Nef protein and } \\
\text { interfere with HIV-1 } \\
\text { replication }\end{array}$ & {$[119-121]$} \\
\hline & & miR-326 & $\begin{array}{l}\text { Nef ORF located in the } 3^{\prime} \text { U3 } \\
\text { of HIV-1 transcripts }\end{array}$ & & $\begin{array}{l}\text { Moderate HIV-1 replication } \\
\text { in human cells }\end{array}$ & [122] \\
\hline & & $\begin{array}{l}\text { miR-423 } \\
\text { miR-301a } \\
\text { miR-155 }\end{array}$ & HIV-1 genome & & $\begin{array}{l}\text { Repress viral gene expres- } \\
\text { sion }\end{array}$ & {$[123]$} \\
\hline & & $\begin{array}{l}\text { miR-28 } \\
\text { miR-125b } \\
\text { miR-150 } \\
\text { miR-223 } \\
\text { miR-382 }\end{array}$ & HIV-1 mRNA $3^{\prime}$ ends & & Contribute to HIV-1 latency & {$[46]$} \\
\hline & & miR-146 & & CXCR4 & Inhibit HIV-1 infection & {$[47,48]$} \\
\hline & & miR-155 & & $\begin{array}{l}\text { ADAM10, TNPO3, Nup153, } \\
\text { LEDGF/p75 }\end{array}$ & Inhibit HIV-1 infection & {$[60]$} \\
\hline & & miR-198 & & Cyclin T1 mRNA & $\begin{array}{l}\text { Restrict HIV-1 replication in } \\
\text { monocytes }\end{array}$ & {$[102]$} \\
\hline & & Let-7i & & IL-2 promoter TATA box & $\begin{array}{l}\text { Activate IL-2 transcrip- } \\
\text { tion, involved in HIV-1 } \\
\text { infection-induced CD4 }{ }^{+} T \\
\text { cell depletion }\end{array}$ & {$[78,137]$} \\
\hline
\end{tabular}


Table 2 Retroviral and host LncRNA

\begin{tabular}{|c|c|c|c|c|c|c|}
\hline & Virus & Name & Viral targets & Cellular targets & Function & References \\
\hline \multirow[t]{3}{*}{ Viral IncRNA } & HIV-1 & $\begin{array}{l}\text { HIV-1-encoded antisense } \\
\text { RNA }\end{array}$ & HIV-1 5' LTR & & $\begin{array}{l}\text { Alter the epigenetic } \\
\text { landscape and silence } \\
\text { the HIV-1 promoter }\end{array}$ & {$[84]$} \\
\hline & HERV-H & HERVH RNA & & p300, OCT4 & $\begin{array}{l}\text { Activate neighboring } \\
\text { genes and in turn regu- } \\
\text { lating pluripotency- } \\
\text { related genes }\end{array}$ & {$[93]$} \\
\hline & HTLV-1 & $\mathrm{HBZ}$ & & E2F1 & $\begin{array}{l}\text { Promote T cell prolifera- } \\
\text { tion }\end{array}$ & {$[97,98]$} \\
\hline \multirow[t]{4}{*}{ Host IncRNA } & & NRON & Tat & NFAT & $\begin{array}{l}\text { Induce the degradation } \\
\text { of Tat and contribute to } \\
\text { HIV-1 latency; suppress } \\
\text { NFAT-mediated viral } \\
\text { gene activation }\end{array}$ & {$[132,135]$} \\
\hline & & NEAT1 & HIV-1 unspliced RNAs & $\begin{array}{l}\text { p54nrb, PSF, Matrin3, } \\
\text { RBM14 }\end{array}$ & $\begin{array}{l}\text { Inhibit nucleus-to-cyto- } \\
\text { plasm export of Rev- } \\
\text { dependent instability } \\
\text { element (INS)-contain- } \\
\text { ing HIV-1 mRNAs }\end{array}$ & {$[104,106,108-110]$} \\
\hline & & 7SK snRNA & & P-TEFb & $\begin{array}{l}\text { Negatively regulate HIV-1 } \\
\text { Tat transcriptional acti- } \\
\text { vation by specifically } \\
\text { sequestering P-TEFb }\end{array}$ & {$[111,112]$} \\
\hline & & 7SL RNA & HIV-1 Gag & APOBEC3G & $\begin{array}{l}\text { Enable efficient packag- } \\
\text { ing of APOBEC } 3 G \text { into } \\
\text { virions }\end{array}$ & [128] \\
\hline
\end{tabular}

is that these extracellular ncRNAs could enter the target cells along with the viruses and affect viral infectivity. The virion-associated ncRNAs might also play certain roles in these steps. A small subset of host miRNAs are shown to be concentrated in the HIV-1 virions by up to 115 folds [45]. Notably, three of the packaged miRNAs: miRNA382, miRNA-223, and miRNA-150, were able to interact with the $3^{\prime}$ UTR of HIV-1 mRNA as well as contribute to HIV-1 latency [46] (see discussion in the non-coding RNAs and retrovirus assembly section below). However, their functions within the virions remain to be determined. It is interesting to investigate whether the noncoding RNAs packaged in virions are involved in viral fusion and uncoating steps, considering they have been protected by the viral particle from the damage caused by the extracellular environment. As mentioned above, these virion-enriched ncRNAs could also affect the expression of entry- or uncoating-related proteins.

As the co-receptor is important for HIV-1 entrance, the dysregulation of CCR5 or CXCR4 significantly affects HIV-1 infection. It has been shown that CXCR4 is a direct target of miR-146a in human hematopoietic normal and leukemic cells; and the transcription factor PLZF (promyelocytic leukemia zinc finger) has been identified as a repressor of miR-146a expression in megakaryocytic (Mk) cells [47]. These authors further reported that the miR-146a upregulation by AMD3100 treatment or PLZF silencing decreases CXCR4 protein expression and prevents HIV-1 infection in monocytic cell line and $\mathrm{CD} 4^{+}$ T lymphocytes [48]. However, the suppression of CXCR4 by miR-146 was not confirmed at least in MT2 cells [49]. At present, there is no solid evidence for CCR5 to be regulated by any cellular or viral microRNA and the HIV-1 infection is therefore affected.

For HIV-1, the initiation of reverse transcription is coupled with the uncoating of the viral core [50]. It is well known that $\mathrm{RNA}_{\mathrm{Lys} 3}$ serves as the primer for reverse transcription of viral genomic RNA. In addition to primer tRNA, the reverse transcription complex (RTC) contains multiple proteins, including viral proteins MA (matrix protein, p17), CA (capsid protein, p24), NC (nucleocapsid protein, p7), IN (integrase), and Vpr [51]. The mature CA protein most likely provides the overall structure of the RTC $[52,53]$. Only a few host proteins have been identified from the RTC. The cellular protein cyclophilin A (CypA) was shown to play a critical role in the correct disassembly of the HIV-1 core early after infection [54]. The APOBEC3 family is involved in the restriction of retrovirus reverse-transcription, functioning as cytosine deaminases that introduce hyper $\mathrm{G}$ to A mutations to the sense strand of proviral cDNA [55]. While no report shows the expression of these host factors is directly regulated by miRNA or other ncRNAs, our studies have shown that APOBEC3G and its family 
members cause derepression of miRNA-mediated protein translation inhibition [56], which is through interfering with the interaction between Argonaute- 2 and MOV10 [57] (Fig. 1I). These findings imply that there could be a complex regulation network involving retroviruses, APOBEC3 proteins and the host miRNA pathway. It will be interesting to investigate the roles of lncRNAs during the assembly of the RTC, e.g. as a scaffold for the complex assembly. It is also intriguing to explore the roles of virion-associated miRNAs during reverse transcription, given that these miRNAs could potentially bind to the $3^{\prime}$ UTR of viral genomic RNA and be packaged into the virions.

At the late stage of the reverse transcription, the RTC transitions into a pre-integration complex (PIC), which is subsequently transported into the nucleus. Similarly, the integration of viral DNA into the host chromosome involves many host factors, such as proteins that help the transfer of viral DNA to nucleus and the integration of viral DNA into the host chromosome. For example, the cellular transcriptional coactivator lens epitheliumderived growth factor (LEDGF)/p75 is an essential HIV integration cofactor, which forms stable tetramers and associates with HIV-1 integrase $[58,59]$. The stimulation of polyinosinic-polycytidylic acid [poly (I:C)] and bacterial lipopolysaccharide (LPS), the ligands for toll-like receptor 3 (TLR3) and TLR4, respectively, are known to decrease HIV-1 infection in monocyte-derived macrophages (MDMs), but the mechanism was unclear. It has been shown that stimulation with poly (I:C) upon TLR3 in MDMs leads to the upregulation of miR-155 expression, and consequently the downregulation of its target proteins including ADAM10, TNPO3, Nup153, and LEDGF/p75. This study indicates that a TLR3-induced miRNA exerts an anti-HIV-1 effect by targeting several HIV-1 dependency factors to inhibit HIV-1 infection [60] (Fig. 1J).

Compared to the late phase, less is known about the early steps of retrovirus life cycle, as reviewed by Nisole and Saib [4]. Accordingly, the roles of non-coding RNAs played during the early phase of retrovirus life cycle are still largely unknown.

\section{Non-coding RNAs and the late phase of the retrovirus life cycle}

\section{Retrovirus-encoded non-coding RNAs}

After integration, the provirus starts to transcribe viral genes. The transcription of the proviral genome leads to generation of diverse products including genomic RNA, spliced mRNAs, structural proteins, accessory proteins, and some non-coding RNAs [61]. These viral parts play various roles in the late stage of retroviral life cycle, and some of them are essential parts of the progeny viruses.
Below we describe the roles played by virus-encoded and cellular non-coding RNAs in the late stage of the retroviral life cycle.

\section{HIV-1-encoded non-coding RNAs}

Virus-encoded miRNAs were initially identified from Epstein-Barr viruses (EBV) [62]. Since then, an increasing number of virus-encoded miRNAs have been identified $[17,63]$. Most of these miRNAs were reported in DNA viruses such as Herpes and Polyoma viruses, but rarely in RNA viruses [17]. Because of the rapid developments of next-generation sequencing (NGS, or deepsequencing) technology, which is much more sensitive and quantitative than the conventional cDNA clone sequencing method, more RNA virus-derived miRNAs have been discovered, especially from HIV-1, West Nile Virus (WNV), and Bovine Leukemia Virus (BLV) [64-67].

It has been reported that HIV-1 encodes miRNAs and other small RNAs. Bennasser et al. first performed a computational prediction of HIV-1-encoded miRNAs and found five pre-miRNA candidates [68]. Subsequently, several groups identified miRNAs from the HIV-1 negative regulatory factor (Nef) and trans-activation response (TAR) element [69-72]. Through the NGS method, a number of HIV-1-encoded small RNAs were discovered, some of which exhibit features of miRNA siRNA [73-75]. HIV-1-derived small RNAs have been shown to modulate cellular and/or viral gene expression. The TARderived miRNA protects the infected cells from apoptosis by downregulating cellular genes involved in apoptosis [71, 76]. A Nef-derived miRNA-miR-N367 blocks HIV-1 Nef expression in vitro [72].

The low abundance of HIV-1-derived small RNAs has fueled the debate about the existence and function of HIV-1-encoded miRNAs [17]. A possible explanation of the low abundance of HIV-1-derived miRNAs is that the virus has been evolving to escape from or counteract the RNAi-mediated immune surveillance. HIV-1 has developed special ways to manipulate the host RNAi, such as using a non-processed transcript to produce miRNAs and targeting viral promoter DNA for the regulation of gene expression. Harwig et al. revealed that nonprocessive transcription from the HIV-1 LTR promoter results in the production of TAR-encoded miRNA-like small RNA [75]. Dicer cleaves these TAR RNAs and the viral transactivating regulatory protein (Tat) stimulates this processing. Through this special biogenesis pathway, HIV-1 produces the TAR-derived miRNA without cleavage of its RNA genome. Through a strategy combining in silico prediction and NGS, our group identified a novel HIV-1-encoded miRNA, miR-H3 [77]. miR-H3 is located in the mRNA region encoding the active center 
of reverse transcriptase (RT), and exhibits high sequence conservation among HIV-1 subtypes. The overexpression of miR-H3 increases viral production, while mutations in the miR-H3 sequence significantly impair the replication of HIV- $1_{\mathrm{NL43}}$, suggesting that it is a viral replicationenhancing miRNA. Interestingly, miR-H3 targets the HIV-1 5' LTR TATA box and sequence-specifically activates the viral promoter transcription. This is the first report of the promoter TATA box-targeting miRNAs that activate gene transcription [77]. These miRNAs might directly interact with the TATA box in the RNA Polymerase II pre-initiation complexes (PICs) and facilitate transcription initiation [78]. In contrast to cytoplasmic miRNAs that need a quite high expression level to bind and regulate their massive mRNA targets, the abundance of the TATA box-targeting miRNAs required for regulating promoter activity is significantly reduced, given that the copy number of their targets in the nucleus is very limited (Fig. 1K).

The secondary structure of the entire HIV-1 RNA genome is quite complicated [79]. Several groups recently found that HIV-1 transcribes not only full-length genomic RNA and multiple spliced mRNAs, but also some antisense RNAs [65, 80-82]. Some of the HIV-1-encoded antisense RNAs can suppress HIV-1 expression [83]. Particularly, one of these suppressive HIV-1-encoded antisense RNAs is a lncRNA [84]. Further experiments showed that this lncRNA could alter the epigenetic landscape of the HIV-1 promoter by recruiting DNA methyltransferase 3A (DNMT3A), enhancer of zeste homolog 2 (EZH2), histone deacetylase 1 (HDAC1), and euchromatic histone-lysine $\mathrm{N}$-methyltransferase 2 (EHMT2, also known as G9a) to the HIV-1 $5^{\prime}$ LTR. These proteins recruited by the antisense lncRNA lead to an epigenetically silenced state of the viral promoter, which is characterized by multiple suppressive epigenetic markers including histone deacetylation, H3K9 dimethylation, and H3K27 trimethylation [84].

\section{Other retrovirus-derived non-coding RNAs}

Interestingly, to prevent the cleavage of their RNA genome, some retroviruses use an alternative RNA source as miRNA precursor. A deltaretrovirus bovine leukemia virus (BLV) uses RNA Pol III transcripts to produce five miRNAs in a Drosha-independent manner [66]. Whisnant et al. identified three miRNAs from bovine foamy virus (BFV), a member of the spumavirus subfamily of retroviruses, in both BFV-infected cultured cells and BFV-infected cattle. All three viral miRNAs are generated from an 122-nucleotide (nt) pri-miRNA encoded within the BFV long terminal repeat U3 region. This BFV pri-miRNA is also transcribed by
RNA polymerase III [85]. In the avian leukosis virus subgroup J (ALV-J), an alpharetrovirus, a miRNA encoded by the exogenous virus-specific (E or XSR) region has been described. Unlike the above reported miRNAs, this miRNA is generated by the canonical miRNA biogenesis pathway. The pri-miRNA is transcribed by RNA Pol II and requires Drosha and Dicer for processing [86]. This finding raises the debate on whether retroviruses can use the canonical miRNA pathway to produce miRNA again.

Besides miRNAs, retroviruses also encode lncRNAs to regulate viral or host genes expression [87]. In recent years, transposable elements (TEs) have been identified as a major lncRNA repertoire, and are treated as functional domains of lncRNAs due to their multiple RNA-, DNA-, and protein-binding properties [88]. Nearly two thirds of the mature lncRNAs are originated from transposable elements (TEs). Among them, ten percent are transcribed from endogenous retrovirus (ERV) [89]. HERV-H is one of the primate-specific endogenous retroviruses that is preferentially expressed in human embryonic stem cells (hESCs) and induced pluripotent stem cells (hiPSCs) [90, 91]. Nearly ten percent of the HERV-H transcripts are lncRNAs [92]. One of the HERV-H-driven lncRNAs was found to interact with the transcriptional coactivator p300 and pluripotency factor OCT4 and enriched in the HERV-H LTR7 regions, resulting in the activation of neighboring genes and in turn regulating pluripotencyrelated genes [93]. In addition to the regulation of hESCs, another ERV-derived IncRNA named Endogenous retroViral-associated ADenocarcinoma RNA (EVADR) was found to be expressed specifically in human adenocarcinoma but not in non-glandular origin tumors [94]. Human T cell leukemia virus type 1 (HTLV-1), a retrovirus of the human T-lymphotropic virus (HTLV) family, is the etiologic agent of adult T-cell leukemia (ATL) [95]. An HTLV-1-encoded protein named HTLV-1 bZIP factor (HBZ) was previously found to suppress the viral Tax expression [96]. Recently, researchers found that the mRNA of $H B Z$ is retained in the nucleus and functions as an IncRNA to promote $T$ cell proliferation [97, 98].

Taken together, some special features of retrovirusderived miRNAs have emerged: (1) biogenesis-retroviruses use both canonical and non-canonical biogenesis pathways to generate miRNA; and (2) mode of actionretrovirus-encoded miRNA target can the promoter TATA box to upregulate gene transcription instead of targeting the mRNA $3^{\prime}$ UTR to suppress translation. These findings extend our understanding of the RNAi pathway in mammalian cells. Although the small size of retroviral RNA genomes has limited their coding ability for ncRNAs, the extraordinary diversity of viral transcripts and 
the enormous host gene regulation network enable the viral ncRNAs unlimited functional potentials.

\section{Cellular non-coding RNAs and retroviral gene expression} During productive infection, plenty of host factors are involved in the transcriptional regulation of viral genes such as the P-TEFb complex and NFk-B $[99,100]$. In addition, massive interactions between viral products and host proteins or ncRNAs occur at different levels. Therefore, viral gene expression might be the most regulated step in the retroviral life cycle.

\section{Host non-coding RNAs regulate viral transcription and RNA transport}

The efficient replication of HIV-1 is dependent on many cellular transcription factors, which could also be the targets of host RNAi. As a subunit of RNA polymerase II elongation factor P-TEFb, Cyclin T1 is required for Tat transactivation of HIV-1 LTR-directed gene expression [101]. MiR-198 is relatively highly expressed in human monocytes compared to macrophages, which are more permissive for HIV-1 replication. By targeting the $3^{\prime}$ UTR of Cyclin T1 mRNA and suppressing its translation, miR-198 functions to restrict HIV-1 replication in monocytes [102]. Many other host miRNA-mediated indirect effects on HIV-1 transcription through targeting the host dependency factors (HDFs) have been summarized by Barichievy et al. [103] (Fig. 1H).

Cellular lncRNAs also participate in the transcriptional regulation as well as the transportation of HIV-1 RNAs. A group identified six lncRNAs that were dysregulated by HIV-1 infection in both Jurkat and MT4 cells, one of which is NEAT1 (Nuclear Paraspeckle Assembly Transcripts 1) [104]. NEAT1 contributes to the formation of paraspeckles through sequestering multiple component proteins [105-107]. Some of the NEAT1-sequestered proteins are pivotal co-factors for efficient HIV-1 gene expression, including p54nrb, PSF, Matrin3, and RBM14 [108-110]. Besides canonical lncRNAs, some non-canonical lncRNAs were also involved in HIV-1 replication [46, 111, 112]. P-TEFb, which is composed of CDK9 and Cyclin T1, is indispensable for efficient HIV-1 transcription [113]. Two independent groups identified that lncRNA 7SK small nuclear RNA (snRNA) can negatively regulate HIV-1 Tat transcriptional activation by specifically sequestering P-TEFb $[111,112]$. In addition, HIV-1 unspliced RNAs can be hijacked in NEAT1-supported nuclear paraspeckles and subjected to RNA editing. Knockdown of NEAT1 significantly enhanced HIV-1 production by increasing nucleus-to-cytoplasm export of Rev-dependent HIV-1 mRNAs containing an instability element (INS) [104].

\section{Host non-coding RNAs directly target HIV-1 RNAs for post-transcriptional suppression}

HIV-1 infection suppresses the RNA interfering pathway of host cells [114]. HIV-1 infection also causes global dysregulation of host miRNA expression profiles [115, 116]. HIV-1 Tat protein is shown to be a suppressor of RNA silencing (SRS), which abrogates the host cells RNA-silencing defense by subverting the ability of Dicer to process precursor double-stranded RNAs into siRNAs [117]. The HIV-1 TAR element was also reported to inhibit the host RNAi pathway by competitively binding to TAR RNA binding protein (TRBP), a cofactor of the key RNAi component Dicer [118]. These findings suggest that HIV-1 is escaping from the restriction imposed by the host RNAi mechanism. In fact, many host miRNAs have been shown to affect HIV-1 replication in direct or indirect ways.

Since HIV-1 is a RNA virus, its genomic RNA is a potential target for host miRNAs. Using in silico approaches, a number of miRNA binding sites in HIV-1 genomic RNA or mRNA transcripts were predicted and subsequently experimentally validated. Hariharan et al. reported that miR-29a and miR-29b were predicted to target HIV-1 Nef transcripts, whereas miR-149, miR378, and miR-324-5p were predicted to target Vpr, Env, and Vif transcripts, respectively. However, these targeting sites were not located in the HIV-1 $3^{\prime}$ LTR [119]. These authors then showed that the cellular miRNA miR-29a downregulates the expression of Nef protein and interferes with HIV-1 replication in HEK293T and Jurkat T cells $[120,121]$. Similarly, Houzet et al. predicted the target sites of 22 human miRNAs in the HIV-1 genome, five of which were capable of inhibiting HIV-1 replication in 42CD4 cells derived from HEK293 cells stably expressing CD4 and CXCR4 [122]. Houzet et al. further demonstrated that the degree of complementarity between the predicted viral sequence and cellular miR-326 correlates with the potency of miRNA-mediated inhibition of viral replication. This finding indicates the selection pressure imposed on HIV-1 by the host RNAi pathway, which may drive the evolution of HIV-1. Using the photoactivatable ribonucleoside-induced cross-linking and immunoprecipitation (PAR-CLIP) technique, Whisnant et al. discovered several binding sites in the HIV-1 genome for cellular miRNAs, a subset of which were capable of repressing viral gene expression, including miR-423, miR301a, and miR-155 [123]. They also argued that HIV-1 transcripts have evolved to avoid inhibition by host miRNAs by adopting extensive RNA secondary structures that occlude most potential miRNA binding sites.

Collectively, the current data show that cellular noncoding RNAs directly or indirectly modulate viral transcription, RNA transportation, and translation. 
Meanwhile, the viruses have been evolving to evade inhibition by the RNAi pathway, which is enabled by their hyper mutation rate as well as the complicated folding of viral RNAs.

\section{Non-coding RNAs and retrovirus assembly: the packaging of non-coding RNAs into retroviral particles}

It was noticed several decades ago that host RNAs could be packaged into retroviral particles [124, 125]. Over $30 \%$ of the RNA in retroviral particles consist of host RNAs. These host RNAs include mRNA, tRNA, and small non-coding RNAs transcribed by Pol III. The most well-known host RNA packaged into HIV-1 virions is tRNA $_{\text {Lys3 }}$, which serves as the primer to initiate HIV-1 reverse transcription [126]. The non-coding RNA 7SL is another highly enriched host RNA identified in HIV-1 virions [127], which is important for the efficient packaging of APOBEC3G into virions [128]. Numerous subsets of endogenous retroelement RNAs expressed in virusproducing cells are also preferentially packaged. For example, intact endogenous retroviral transcripts like the murine VL30 elements are packaged by murine leukemia virus (MLV); and fragments of non-long terminal repeats (LTR) retroelements such as the transcripts of divergent and truncated Long INterspersed Elements (LINEs) are packaged into virions by HIV-1 $[129,130]$.

Through the NGS technology, a pile of host miRNAs was found to be selectively packaged into HIV-1 virions and affect viral infectivity (Fig. 1L). Using the SOLiD sequencing platform, Schopman et al. examined the miRNA profiling in a $\mathrm{T}$ cell line and several primary cell subsets before and after HIV-1 infection. They also examined the miRNAs in HIV-1 particles, and found that a small subset of the host miRNAs is dramatically concentrated in the virions by up to 115 folds [45]. Notably, three of the packaged miRNAs: miRNA-382, miRNA-223, and miRNA-150, are shown to contribute to HIV-1 latency [46]. Later, Bogerd et al. used the Illumina Hiseq 2000 system to investigate the packaging of cellular miRNAs into HIV-1 virions produced from CEM-SS T cells. However, they just found a 2- to 4-fold enrichment of five host miRNAs in virions. Among them, miR-155 and miR-92a were reported previously to weakly bind HIV-1 transcripts [123]. Interestingly, an artificial miRNA target site introduced into the viral genome resulted in 10- to 40 -fold increase in the packaging of the cognate miRNAs into virions, which significantly inhibited HIV-1 virion infectivity [131]. Nevertheless, it remains to be clarified how these virion-enriched miRNAs exert their functions during the early phase of the HIV-1 life cycle. It is possible that these virion-enriched miRNAs can inhibit viral reverse transcription or regulate the genes needed for viral entry or uncoating, as we discussed above regarding the roles of ncRNAs in the early phase of retroviral life cycle.

\section{Non-coding RNAs and retroviral latency}

Given the inhibitory effect on gene expression mediated by miRNAs, it is intriguing to investigate the roles of host miRNAs in HIV-1 latency. Our group reported that cellular miRNAs potently inhibit HIV-1 production in resting primary $\mathrm{CD} 4^{+} \mathrm{T}$ cells and contribute to HIV-1 latency [46]. We showed that the $3^{\prime}$ ends of HIV-1 messenger RNAs are targeted by several cellular miRNAs including miR-28, miR-125b, miR-150, miR-223, and miR-382, which are enriched in resting $\mathrm{CD} 4^{+} \mathrm{T}$ cells compared to activated $\mathrm{CD} 4^{+} \mathrm{T}$ cells. Specific inhibitors of these miRNAs activate HIV-1 protein translation in resting $\mathrm{CD}^{+}$ $\mathrm{T}$ cells transfected with HIV-1 infectious clones as well as viral production from resting $\mathrm{CD} 4^{+} \mathrm{T}$ cells isolated from HIV-1-infected individuals on suppressive combined antiretroviral therapy (cART) [46]. This is the first report showing that cellular miRNAs contribute to HIV-1 latency, which adds a new layer to the mechanisms of the establishment of HIV-1 latency (Fig. 1M).

In addition to miRNAs, lncRNAs have also been found to be involved in the regulation of HIV-1 latency. Recently, we found a cellular lncRNA-noncoding repressor of NFAT (NRON), which is highly expressed in resting $\mathrm{CD}^{+} \mathrm{T}$ lymphocytes, contributes to HIV-1 latency [132]. Knockdown of NRON in latently infected resting $\mathrm{CD}^{+} \mathrm{T}$ cells significantly enhanced HIV-1 expression without activating the cells. Early studies showed that NRON acts as a negative regulator of transcription factor NFAT, which promotes HIV-1 expression by binding to the downstream of TAR [133, 134]. NRON hijacks NFAT in the cytoplasm to suppress NFAT-mediated viral gene activation. Another group also suggested that the NRON levels were reduced by the early viral accessory protein Nef and increased by the late protein Vpu [135]. However, we found that the expression of NFAT in HIV-1 latently-infected resting $\mathrm{CD} 4^{+} \mathrm{T}$ cells is quite low. The mutation of NFAT binding sites in the HIV-1 $5^{\prime}$ LTR did not abolish NRON-mediated suppression of HIV-1 transcription. These findings indicate that the suppression of HIV-1 activation by NORN is independent of NFAT in resting $\mathrm{CD}^{+} \mathrm{T}$ cells. Intriguingly, the expression of the HIV-1 transactivator Tat decreased significantly upon NRON overexpression. Further investigations showed that NRON directly links Tat to the ubiquitin/proteasome components including CUL4B and PSMD11 to specifically induce Tat degradation, thus facilitating HIV-1 latency (Fig. 1N). Collectively, these data suggest that NRON modulates HIV-1 latency in both NFAT-dependent and -independent manners. In addition, another group reported that an HIV-1 antisense transcript 
called ASP interacts with polycomb repressor complex 2 (PRC2) and recruits PRC2 to the HIV-1 5' LTR. This induces the accumulation of suppressive H3K27 trimethylation and reduces viral transcription, which facilitates the establishment of HIV-1 latency [136].

\section{Non-coding RNAs and retrovirus pathogenesis}

Retrovirus infection causes severe diseases such as cancers and AIDS. As key regulators of cellular processes, non-coding RNAs are involved in the progression of diseases caused by retroviruses. We showed that HIV-1 infection decreases the expression of a cellular miRNA let-7i in $\mathrm{CD} 4^{+} \mathrm{T}$ cells by attenuating the transcription of its precursor [137]. Let-7i activates the transcription of cytokine interleukin-2 (IL-2) through targeting its promoter TATA box region [78]. It has been observed for a long time that HIV-1 infection causes a decrease in IL-2 levels, which is one of the causes of $\mathrm{CD}^{+} \mathrm{T}$ cell depletion, but the mechanism was not clear. Our findings reveal a novel pathway that the HIV-1 infection-induced suppression of the let-7i/IL- 2 axis contributes to $\mathrm{CD} 4^{+}$ $T$ cell death [137]. Another interesting study showed that the BLV-miR-B4 shares an identical seed sequence with the cellular pro-oncogene miR-29, and both downregulate a similar set of mRNA targets [138]. Given that miR-29 overexpression is associated with B-cell neoplasms that resemble BLV-associated tumors, these findings suggest a possible miRNA-mediated mechanism contributing to BLV-induced tumorigenesis [66]. Other support for their roles in tumor onset and progression is that these miRNAs are highly expressed in preleukemic and malignant cells in which viral structural and regulatory gene expression was repressed [138]. The increasing ncRNA expression profiling data during viral infection are very helpful to identify those ncRNAs that are involved in retroviral pathogenesis.

\section{Application of non-coding RNA approaches in the specific treatment of retrovirus-related diseases}

Since non-coding RNAs can sequence-specifically block retrovirus or host factors required for viral replication, non-coding RNAs are ideal candidates for the treatment of retrovirus infection. HIV-1 latency in resting $\mathrm{CD}^{+}$ $\mathrm{T}$ cells is a major obstacle for the eradication of viruses from HIV-1-infected patients receiving combination antiretroviral therapy (cART) $[3,5]$. The "shock and kill" strategy aims to activate the latently-infected viruses and induce the killing of the infected cells by specific cytotoxic effects [139]. Several approaches have been developed to activate latent virus transcription for killing, including by activating T lymphocytes with IL-2 or IL-2 plus anti-CD3/anti-CD28 antibody [140, 141], protein kinase C (PKC) activators (e.g. prostatin [142]), or activating transcription with histone deacetylases inhibitors (HDACi) without inducing host cell activation (such as valproic acid [VPA], suberoylanilide hydroxamic acid [SAHA]) [143-145]. However, the first approach has been shown to cause serious cytotoxic effects, while PKC agonists and HDACi are speculated to cause global gene expression activation with unpredictable side effects. Thus, an HIV-1 provirus-specific activating reagent is ideal for purging the latent reservoir. Our study demonstrated that the HIV-1-encoded miRNA miR-H3 could activate HIV-1 transcription in a sequence-specific manner [77] (Fig. 1K). Together with our previous findings that some cellular miRNAs contribute to the latency of HIV-1 by inhibiting HIV-1 production [46], a combination of the HIV-1 TATA box-targeting small RNA(s) and the inhibitors of these cellular miRNAs could provide an HIV-1-specific and much safer approach for activating and eradicating the HIV-1 latent reservoir [146]. In addition, lncRNAs could also be good candidates for activating HIV-1 latency. The depletion of NRON, especially in combination with a histone deacetylase (HDAC) inhibitor, significantly reactivates viral production from HIV-1-latently infected primary $\mathrm{CD}^{+}{ }^{+} \mathrm{T}$ lymphocytes [132]. Collectively, our data demonstrate that non-coding RNAs could be used for the development of more effective and virus-specific latency-reversing agents [146]. Considering the significant sequence variations among different strains of retrovirus, such as HIV-1, even within a single infected individual [147], the efficacy of single small ncRNA, e.g. siRNA or miRNA, targeting the viral transcripts must vary as well. A combination of small ncRNAs that target multiple conservative sites of the viral sequence will prevent the rise of escape mutants. Moreover, the delivery efficiency of ncRNAs to infected cells needs to be further improved in the future.

\section{Conclusion and future perspectives}

Recent advances in the study of ncRNAs have greatly improved our understanding of retroviral replication, pathogenesis, and evasion from the host immune surveillance. The advent of next-generation sequencing technology, in particular, has completely changed the field of non-coding RNA research. The NGS has two main advantages compared to the classic Sanger sequencing: (1) depth, the NGS is also called deep-sequencing due to its capability to capture extreme low profiling RNA transcripts; (2) accuracy, NGS can provide both quantitative expression data (reads) and the sequence of individual RNA molecules. The successful applications of NGS in retrovirus ncRNA research have been proven by the identification of retrovirus-derived small ncRNAs $[129,130]$ and host small RNAs packaged into viral particles [45]. Moreover, NGS-based novel technologies 
such as ChIP-Seq (Chromatin ImmunoPrecipitationsequencing) and CLIP-Seq (CrossLinking ImmunoPrecipitation-sequencing) are powerful for functional analysis of non-coding RNAs [148, 149]. However, when NGS is used to study ncRNAs in a retrovirus system, some precautions need to be taken: (1) it is important to distinguish "noise" and "signal", as many low- or even high-abundant RNAs are random degradation products instead of functional molecules. In such cases, functional assays must be conducted carefully with a variety of independent approaches [77]. (2) The usage of different cell types, different protocols of viral infection such as viral titer, infection time etc., will result in differing NGS data. Therefore, the comparison of NGS data from heterogeneous sample preparations is a reliable way to identify retrovirus-derived ncRNAs and infer their roles in viral infection [123].

The study of non-coding RNAs in the retrovirus system has revealed a whole new layer of viral replication and virus-host interactions. The reports cited in this review have shown that ncRNAs are involved in the key steps of the retroviral life cycle, especially during the late phase of infection: viral transcription, translation, and assembly, as well as latency and pathogenesis (Fig. 1, Tables 1,2). In contrast, much less is known about the roles of ncRNAs in the early phase of the retrovirus life cycle, which deserve further investigation. The increasing understanding of ncRNAs and their interactions with retroviruses will eventually benefit the therapy of retrovirus-related diseases.

\section{Authors' contributions}

$\mathrm{YZ}$ and $\mathrm{HZ}$ conceived the paper. $\mathrm{XZ}, \mathrm{XM}, \mathrm{SJ}$ and $\mathrm{YZ}$ wrote the manuscript, under the guidance of $\mathrm{HZ}$. YZ prepared the figure. All authors read and approved the final manuscript

\section{Author details}

${ }^{1}$ Institute of Human Virology, Zhongshan School of Medicine, Sun Yat-Sen University, Guangzhou 510080, China. ${ }^{2}$ Key Laboratory of Tropical Disease Control of Ministry of Education, Zhongshan School of Medicine, Sun Yat-Sen University, Guangzhou 510080, China. ${ }^{3}$ Guangdong Engineering Research Center for Antimicrobial Agent and Immunotechnology, Zhongshan School of Medicine, Sun Yat-Sen University, Guangzhou 510080, China. ${ }^{4}$ Section of Infectious Diseases, Department of Internal Medicine, Yale University School of Medicine, New Haven, CT 06520, USA.

\section{Competing interests}

The authors declare that they have no competing interests.

\section{Ethics approval and consent to participate}

Not applicable.

\section{Funding}

This work was funded by Natural Science Foundation of China (NSFC)-NIH of US Project (No. 81561128007), Key Project of NSFC (No. 81730060), Guangdong Innovative Research Team Program (No. 2009010058), and the Jointinnovation Program in Healthcare for Special Scientific Research Projects of Guangzhou, China (201508020256) to HZ.

\section{Publisher's Note}

Springer Nature remains neutral with regard to jurisdictional claims in published maps and institutional affiliations.

Received: 16 August 2017 Accepted: 31 January 2018

Published online: 09 February 2018

\section{References}

1. Coffin JM. Genetic diversity and evolution of retroviruses. Curr Top Microbiol Immunol. 1992;176:143-64.

2. Coffin JM, Hughes SH, Varmus HE, editors. Retroviruses. Cold Spring Harbor: Cold Spring Harbor Laboratory Press; 1997.

3. Chun TW, Stuyver L, Mizell SB, Ehler LA, Mican JA, Baseler M, Lloyd AL, Nowak MA, Fauci AS. Presence of an inducible HIV-1 latent reservoir during highly active antiretroviral therapy. Proc Natl Acad Sci USA. 1997:94:13193-7.

4. Nisole S, Saib A. Early steps of retrovirus replicative cycle. Retrovirology. 2004; 1:9.

5. Siliciano RF, Greene WC. HIV latency. Cold Spring Harb Perspect Med. 2011;1:a007096.

6. Goff SP. Host factors exploited by retroviruses. Nat Rev Microbiol. 2007;5:253-63.

7. Cullen BR. The virology-RNA biology connection. RNA. 2015;21:592-4.

8. Miura K, Watanabe K, Sugiura M, Shatkin AJ. The 5'-terminal nucleotide sequences of the double-stranded RNA of human reovirus. Proc Natl Acad Sci USA. 1974;71:3979-83.

9. Berget SM, Moore C, Sharp PA. Spliced segments at the $5^{\prime}$ terminus of adenovirus 2 late mRNA. Proc Natl Acad Sci USA. 1977;74:3171-5.

10. Schmitt P, Gattoni R, Keohavong P, Stevenin J. Alternative splicing of E1A transcripts of adenovirus requires appropriate ionic conditions in vitro. Cell. 1987;50:31-9.

11. Malim MH, Hauber J, Le SY, Maizel JV, Cullen BR. The HIV-1 rev transactivator acts through a structured target sequence to activate nuclear export of unspliced viral mRNA. Nature. 1989;338:254-7.

12. Fischer U, Huber J, Boelens WC, Mattaj IW, Luhrmann R. The HIV-1 Rev activation domain is a nuclear export signal that accesses an export pathway used by specific cellular RNAs. Cell. 1995;82:475-83.

13. Consortium EP. An integrated encyclopedia of DNA elements in the human genome. Nature. 2012;489:57-74.

14. Eddy SR. Non-coding RNA genes and the modern RNA world. Nat Rev Genet. 2001;2:919-29.

15. Mattick JS, Makunin IV. Non-coding RNA. Hum Mol Genet. 2006;15(Spec No 1):R17-29.

16. Voinnet $\mathrm{O}$. Induction and suppression of RNA silencing: insights from viral infections. Nat Rev Genet. 2005;6:206-20.

17. Umbach JL, Cullen BR. The role of RNAi and microRNAs in animal virus replication and antiviral immunity. Genes Dev. 2009;23:1151-64.

18. Rand TA, Petersen S, Du F, Wang X. Argonaute2 cleaves the anti-guide strand of siRNA during RISC activation. Cell. 2005;123:621-9.

19. Aoki K, Moriguchi H, Yoshioka T, Okawa K, Tabara H. In vitro analyses of the production and activity of secondary small interfering RNAs in C. elegans. EMBO J. 2007:26:5007-19.

20. Diaz-Pendon JA, Li F, Li WX, Ding SW. Suppression of antiviral silencing by cucumber mosaic virus $2 \mathrm{~b}$ protein in Arabidopsis is associated with drastically reduced accumulation of three classes of viral small interfering RNAs. Plant Cell. 2007;19:2053-63.

21. Sen GC. Viruses and interferons. Annu Rev Microbiol. 2001;55:255-81.

22. Bartel DP. MicroRNAs: genomics, biogenesis, mechanism, and function. Cell. 2004;116:281-97.

23. Bushati N, Cohen SM. microRNA functions. Annu Rev Cell Dev Biol. 2007;23:175-205.

24. Lee Y, Ahn C, Han J, Choi H, Kim J, Yim J, Lee J, Provost P, Radmark O, Kim $\mathrm{S}$, Kim VN. The nuclear RNase III Drosha initiates microRNA processing. Nature. 2003:425:415-9. 
25. Yi R, Qin Y, Macara IG, Cullen BR. Exportin-5 mediates the nuclear export of pre-microRNAs and short hairpin RNAs. Genes Dev. 2003;17:3011-6.

26. Hutvagner G, McLachlan J, Pasquinelli AE, Balint E, Tuschl T, Zamore PD. A cellular function for the RNA-interference enzyme Dicer in the maturation of the let-7 small temporal RNA. Science. 2001;293:834-8.

27. Gregory RI, Chendrimada TP, Cooch N, Shiekhattar R. Human RISC couples microRNA biogenesis and posttranscriptional gene silencing. Cell. 2005;123:631-40.

28. Lytle JR, Yario TA, Steitz JA. Target mRNAs are repressed as efficiently by microRNA-binding sites in the $5^{\prime}$ UTR as in the $3^{\prime}$ UTR. Proc Natl Acad Sci USA. 2007;104:9667-72.

29. Tay Y, Zhang J, Thomson AM, Lim B, Rigoutsos I. MicroRNAs to Nanog, Oct4 and Sox 2 coding regions modulate embryonic stem cell differentiation. Nature. 2008;455:1124-8.

30. Orom UA, Nielsen FC, Lund AH. MicroRNA-10a binds the $5^{\prime}$ UTR of ribosomal protein mRNAs and enhances their translation. Mol Cell. 2008;30:460-71.

31. Vasudevan S, Tong Y, Steitz JA. Switching from repression to activation: microRNAs can up-regulate translation. Science. 2007;318:1931-4.

32. Zhang Y, Zhang H. RNAa induced by TATA box-targeting MicroRNAs. Adv Exp Med Biol. 2017;983:91-111.

33. Gagnon KT, Corey DR. Argonaute and the nuclear RNAs: new pathways for RNA-mediated control of gene expression. Nucleic Acid Ther. 2012;22:3-16

34. Portnoy V, Huang V, Place RF, Li LC. Small RNA and transcriptional upregulation. Wiley Interdiscip Rev RNA. 2011;2:748-60.

35. Li LC. Small RNA-guided transcriptional gene activation (RNAa) in mammalian cells. Adv Exp Med Biol. 2017;983:1-20.

36. Harrow J, Frankish A, Gonzalez JM, Tapanari E, Diekhans M, Kokocinski F, Aken BL, Barrell D, Zadissa A, Searle S, et al. GENCODE: the reference human genome annotation for The ENCODE Project. Genome Res. 2012;22:1760-74.

37. Rinn JL, Chang HY. Genome regulation by long noncoding RNAs. Annu Rev Biochem. 2012;81:145-66.

38. Wutz A. Gene silencing in X-chromosome inactivation: advances in understanding facultative heterochromatin formation. Nat Rev Genet. 2011;12:542-53.

39. Li Y, Syed J, Sugiyama H. RNA-DNA triplex formation by long noncoding RNAs. Cell Chem Biol. 2016;23:1325-33.

40. Yang Z, Zhou L, Wu LM, Lai MC, Xie HY, Zhang F, Zheng SS. Overexpression of long non-coding RNA HOTAIR predicts tumor recurrence in hepatocellular carcinoma patients following liver transplantation. Ann Surg Oncol. 2011;18:1243-50.

41. Kogo R, Shimamura T, Mimori K, Kawahara K, Imoto S, Sudo T, Tanaka F, Shibata K, Suzuki A, Komune S, et al. Long noncoding RNA HOTAIR regulates polycomb-dependent chromatin modification and is associated with poor prognosis in colorectal cancers. Cancer Res. 2011;71:6320-6.

42. Gupta RA, Shah N, Wang KC, Kim J, Horlings HM, Wong DJ, Tsai MC, Hung T, Argani P, Rinn JL, et al. Long non-coding RNA HOTAIR reprograms chromatin state to promote cancer metastasis. Nature. 2010;464:1071-6.

43. Turchinovich A, Weiz L, Langheinz A, Burwinkel B. Characterization of extracellular circulating microRNA. Nucleic Acids Res. 2011;39:7223-33.

44. Prensner JR, lyer MK, Balbin OA, Dhanasekaran SM, Cao Q, Brenner JC, Laxman B, Asangani IA, Grasso CS, Kominsky HD, et al. Transcriptome sequencing across a prostate cancer cohort identifies PCAT-1, an unannotated lincRNA implicated in disease progression. Nat Biotechnol. 2011;29:742-9.

45. Schopman NC, van Montfort T, Willemsen M, Knoepfel SA, Pollakis G, van Kampen A, Sanders RW, Haasnoot J, Berkhout B. Selective packaging of cellular miRNAs in HIV-1 particles. Virus Res. 2012;169:438-47.

46. Huang J, Wang F, Argyris E, Chen K, Liang Z, Tian H, Huang W, Squires K, Verlinghieri $\mathrm{G}$, Zhang $\mathrm{H}$. Cellular microRNAs contribute to HIV-1 latency in resting primary CD4 ${ }^{+}$T lymphocytes. Nat Med. 2007;13:1241-7.

47. Labbaye C, Spinello I, Quaranta MT, Pelosi E, Pasquini L, Petrucci E, Biffoni M, Nuzzolo ER, Billi M, Foa R, et al. A three-step pathway comprising PLZF/miR-146a/CXCR4 controls megakaryopoiesis. Nat Cell Biol. 2008;10:788-801.

48. Quaranta MT, Olivetta E, Sanchez M, Spinello I, Paolillo R, Arenaccio C, Federico M, Labbaye C. miR-146a controls CXCR4 expression in a pathway that involves PLZF and can be used to inhibit HIV-1 infection of CD4(+) Tlymphocytes. Virology. 2015;478:27-38.

49. Reynoso R, Laufer N, Hackl M, Skalicky S, Monteforte R, Turk G, Carobene M, Quarleri J, Cahn P, Werner R, et al. MicroRNAs differentially present in the plasma of HIV elite controllers reduce HIV infection in vitro. Sci Rep. 2014:4:5915.

50. Zhang H, Dornadula G, Orenstein J, Pomerantz RJ. Morphologic changes in human immunodeficiency virus type 1 virions secondary to intravirion reverse transcription: evidence indicating that reverse transcription may not take place within the intact viral core. J Hum Virol. 2000:3:165-72.

51. Hu WS, Hughes SH. HIV-1 reverse transcription. Cold Spring Harb Perspect Med. 2012;2:a006882.

52. Qi M, Yang R, Aiken C. Cyclophilin A-dependent restriction of human immunodeficiency virus type 1 capsid mutants for infection of nondividing cells. J Virol. 2008;82:12001-8.

53. Yamashita M, Emerman M. Capsid is a dominant determinant of retrovirus infectivity in nondividing cells. J Virol. 2004;78:5670-8.

54. Braaten D, Franke EK, Luban J. Cyclophilin A is required for an early step in the life cycle of human immunodeficiency virus type 1 before the initiation of reverse transcription. J Virol. 1996;70:3551-60.

55. Zhang H, Yang B, Pomerantz RJ, Zhang C, Arunachalam SC, Gao L. The cytidine deaminase CEM15 induces hypermutation in newly synthesized HIV-1 DNA. Nature. 2003;424:94-8.

56. Huang J, Liang Z, Yang B, Tian H, Ma J, Zhang H. Derepression of microRNA-mediated protein translation inhibition by apolipoprotein $B$ mRNA-editing enzyme catalytic polypeptide-like 3G (APOBEC3G) and its family members. J Biol Chem. 2007;282:33632-40.

57. Liu C, Zhang X, Huang F, Yang B, Li J, Liu B, Luo H, Zhang P, Zhang H. APOBEC3G inhibits microRNA-mediated repression of translation by interfering with the interaction between Argonaute-2 and MOV10. J Biol Chem. 2012;287:29373-83.

58. Llano M, Saenz DT, Meehan A, Wongthida P, Peretz M, Walker WH, Teo W, Poeschla EM. An essential role for LEDGF/p75 in HIV integration. Science. 2006;314:461-4.

59. Cherepanov P, Maertens G, Proost P, Devreese B, Van Beeumen J, Engelborghs Y, De Clercq E, Debyser Z. HIV-1 integrase forms stable tetramers and associates with LEDGF/p75 protein in human cells. J Biol Chem. 2003;278:372-81.

60. Swaminathan G, Rossi F, Sierra LJ, Gupta A, Navas-Martin S, MartinGarcia J. A role for microRNA-155 modulation in the anti-HIV-1 effects of Toll-like receptor 3 stimulation in macrophages. PLoS Pathog. 2012;8:e1002937.

61. Ocwieja KE, Sherrill-Mix S, Mukherjee R, Custers-Allen R, David P, Brown M, Wang S, Link DR, Olson J, Travers K, et al. Dynamic regulation of HIV-1 mRNA populations analyzed by single-molecule enrichment and longread sequencing. Nucleic Acids Res. 2012;40:10345-55.

62. Pfeffer S, Zavolan M, Grasser FA, Chien M, Russo JJ, Ju J, John B, Enright AJ, Marks D, Sander C, Tuschl T. Identification of virus-encoded microRNAs. Science. 2004;304:734-6.

63. Pfeffer S, Sewer A, Lagos-Quintana M, Sheridan R, Sander C, Grasser FA, van Dyk LF, Ho CK, Shuman S, Chien M, et al. Identification of microRNAs of the herpesvirus family. Nat Methods. 2005;2:269-76.

64. Klase ZA, Sampey GC, Kashanchi F. Retrovirus infected cells contain viral microRNAs. Retrovirology. 2013;10:15.

65. Schopman NC, Willemsen M, Liu YP, Bradley T, van Kampen A, Baas F, Berkhout B, Haasnoot J. Deep sequencing of virus-infected cells reveals HIV-encoded small RNAs. Nucleic Acids Res. 2012;40:414-27.

66. Kincaid RP, Burke JM, Sullivan CS. RNA virus microRNA that mimics a B-cell oncomiR. Proc Natl Acad Sci USA. 2012;109:3077-82.

67. Hussain M, Torres S, Schnettler E, Funk A, Grundhoff A, Pijlman GP, Khromykh AA, Asgari S. West Nile virus encodes a microRNA-like small RNA in the $3^{\prime}$ untranslated region which up-regulates GATA4 mRNA and facilitates virus replication in mosquito cells. Nucleic Acids Res. 2012;40:2210-23.

68. Bennasser Y, Le SY, Yeung ML, Jeang KT. HIV-1 encoded candidate micro-RNAs and their cellular targets. Retrovirology. 2004;1:43.

69. Klase Z, Kale P, Winograd R, Gupta MV, Heydarian M, Berro R, McCaffrey T, Kashanchi F. HIV-1 TAR element is processed by Dicer to yield a viral micro-RNA involved in chromatin remodeling of the viral LTR. BMC Mol Biol. 2007;8:63. 
70. Ouellet DL, Plante I, Landry P, Barat C, Janelle ME, Flamand L, Tremblay MJ, Provost P. Identification of functional microRNAs released through asymmetrical processing of HIV-1 TAR element. Nucleic Acids Res. 2008;36:2353-65.

71. Klase Z, Winograd R, Davis J, Carpio L, Hildreth R, Heydarian M, Fu S, McCaffrey T, Meiri E, Ayash-Rashkovsky M, et al. HIV-1 TAR miRNA protects against apoptosis by altering cellular gene expression. Retrovirology. 2009;6:18.

72. Omoto S, Ito M, Tsutsumi Y, Ichikawa Y, Okuyama H, Brisibe EA, Saksena NK, Fujii YR. HIV-1 nef suppression by virally encoded microRNA. Retrovirology. 2004;1:44.

73. Schopman NC, Willemsen M, Liu YP, Bradley T, van Kampen A, Baas F, Berkhout B, Haasnoot J. Deep sequencing of virus-infected cells reveals HIV-encoded small RNAs. Nucleic Acids Res. 2011;40:414-27.

74. Yeung ML, Bennasser Y, Watashi K, Le SY, Houzet L, Jeang KT. Pyrosequencing of small non-coding RNAs in HIV-1 infected cells: evidence for the processing of a viral-cellular double-stranded RNA hybrid. Nucleic Acids Res. 2009;37:6575-86.

75. Harwig A, Jongejan A, van Kampen AH, Berkhout B, Das AT. Tat-dependent production of an HIV-1 TAR-encoded miRNA-like small RNA. Nucleic Acids Res. 2016;44(9):4340-53.

76. Ouellet DL, Vigneault-Edwards J, Letourneau K, Gobeil LA, Plante I, Burnett JC, Rossi JJ, Provost P. Regulation of host gene expression by HIV-1 TAR microRNAs. Retrovirology. 2013;10:86.

77. Zhang Y, Fan M, Geng G, Liu B, Huang Z, Luo H, Zhou J, Guo X, Cai W, Zhang $H$. A novel HIV-1-encoded microRNA enhances its viral replication by targeting the TATA box region. Retrovirology. 2014;11:23.

78. Zhang Y, Fan M, Zhang X, Huang F, Wu K, Zhang J, Liu J, Huang Z, Luo $\mathrm{H}$, Tao L, Zhang H. Cellular microRNAs up-regulate transcription via interaction with promoter TATA-box motifs. RNA. 2014;20:1878-89.

79. Watts JM, Dang KK, Gorelick RJ, Leonard CW, Bess JW Jr, Swanstrom R, Burch CL, Weeks KM. Architecture and secondary structure of an entire HIV-1 RNA genome. Nature. 2009:460:711-6.

80. Harwig A, Das AT, Berkhout B. HIV-1 RNAs: sense and antisense, large mRNAs and small siRNAs and miRNAs. Curr Opin HIV AIDS. 2015;10:103-9.

81. Ludwig LB, Ambrus JL Jr, Krawczyk KA, Sharma S, Brooks S, Hsiao CB, Schwartz SA. Human immunodeficiency virus-type 1 LTR DNA contains an intrinsic gene producing antisense RNA and protein products. Retrovirology. 2006;3:80.

82. Landry S, Halin M, Lefort S, Audet B, Vaquero C, Mesnard JM, Barbeau B. Detection, characterization and regulation of antisense transcripts in HIV-1. Retrovirology. 2007;4:71.

83. Kobayashi-Ishihara M, Yamagishi M, Hara T, Matsuda Y, Takahashi R Miyake A, Nakano K, Yamochi T, Ishida T, Watanabe T. HIV-1-encoded antisense RNA suppresses viral replication for a prolonged period. Retrovirology. 2012;9:38.

84. Saayman S, Ackley A, Turner A-MW, Famiglietti M, Bosque A, Clemson M, Planelles V, Morris KV. An HIV-encoded antisense long noncoding RNA epigenetically regulates viral transcription. Mol Ther. 2014;22:1164-75.

85. Whisnant AW, KehI T, Bao Q, Materniak M, Kuzmak J, Lochelt M, Cullen BR. Identification of novel, highly expressed retroviral microRNAs in cells infected by bovine foamy virus. J Virol. 2014;88:4679-86.

86. Yao Y, Smith LP, Nair $V$, Watson M. An avian retrovirus uses canonical expression and processing mechanisms to generate viral microRNA. J Virol. 2014;88:2-9.

87. Kapusta A, Feschotte C. Volatile evolution of long noncoding RNA repertoires: mechanisms and biological implications. Trends Genet. 2014;30:439-52.

88. Johnson R, Guigo R. The RIDL hypothesis: transposable elements as functional domains of long noncoding RNAs. RNA. 2014;20:959-76.

89. Kapusta A, Kronenberg Z, Lynch VJ, Zhuo X, Ramsay L, Bourque G, Yandell $M$, Feschotte $C$. Transposable elements are major contributors to the origin, diversification, and regulation of vertebrate long noncoding RNAs. PLoS Genet. 2013;9:e1003470.

90. Santoni FA, Guerra J, Luban J. HERV-H RNA is abundant in human embryonic stem cells and a precise marker for pluripotency. Retrovirology. 2012;9:111.

91. Wang J, Xie G, Singh M, Ghanbarian AT, Rasko T, Szvetnik A, Cai H, Besser D, Prigione A, Fuchs NV, et al. Primate-specific endogenous retrovirus-driven transcription defines naive-like stem cells. Nature. 2014;516:405-9.

92. Kelley D, Rinn J. Transposable elements reveal a stem cell-specific class of long noncoding RNAs. Genome Biol. 2012;13:R107.

93. Lu X, Sachs F, Ramsay L, Jacques PE, Goke J, Bourque G, Ng HH. The retrovirus HERVH is a long noncoding RNA required for human embryonic stem cell identity. Nat Struct Mol Biol. 2014;21:423-5.

94. Gibb EA, Warren RL, Wilson GW, Brown SD, Robertson GA, Morin GB, Holt RA. Activation of an endogenous retrovirus-associated long noncoding RNA in human adenocarcinoma. Genome Med. 2015;7(1):22.

95. Poiesz BJ, Ruscetti FW, Gazdar AF, Bunn PA, Minna JD, Gallo RC. Detection and isolation of type $C$ retrovirus particles from fresh and cultured lymphocytes of a patient with cutaneous T-cell lymphoma. Proc Natl Acad Sci USA. 1980;77:7415-9.

96. Mesnard JM, Barbeau B, Devaux C. HBZ, a new important player in the mystery of adult T-cell leukemia. Blood. 2006;108:3979-82.

97. Satou Y, Yasunaga J, Yoshida M, Matsuoka M. HTLV-I basic leucine zipper factor gene mRNA supports proliferation of adult T cell leukemia cells. Proc Natl Acad Sci USA. 2006;103:720-5.

98. Rende F, Cavallari I, Corradin A, Silic-Benussi M, Toulza F, Toffolo GM, Tanaka Y, Jacobson S, Taylor GP, D'Agostino DM, et al. Kinetics and intracellular compartmentalization of HTLV-1 gene expression: nuclear retention of HBZ mRNAs. Blood. 2011;117:4855-9.

99. Zhou H, Xu M, Huang Q, Gates AT, Zhang XD, Castle JC, Stec E, Ferrer M, Strulovici B, Hazuda DJ, Espeseth AS. Genome-scale RNAi screen for host factors required for HIV replication. Cell Host Microbe. 2008:4:495-504.

100. Brass AL, Dykxhoorn DM, Benita Y, Yan N, Engelman A, Xavier RJ, Lieberman J, Elledge SJ. Identification of host proteins required for HIV infection through a functional genomic screen. Science. 2008;319:921-6.

101. Wei P, Garber ME, Fang SM, Fischer WH, Jones KA. A novel CDK9-associated C-type cyclin interacts directly with HIV-1 Tat and mediates its high-affinity, loop-specific binding to TAR RNA. Cell. 1998:92:451-62.

102. Sung TL, Rice AP. miR-198 inhibits HIV-1 gene expression and replication in monocytes and its mechanism of action appears to involve repression of cyclin T1. PLoS Pathog. 2009;5:e1000263.

103. Barichievy S, Naidoo J, Mhlanga MM. Non-coding RNAs and HIV: viral manipulation of host dark matter to shape the cellular environment. Front Genet. 2015;6:108.

104. Zhang Q, Chen CY, Yedavalli VS, Jeang KT. NEAT1 long noncoding RNA and paraspeckle bodies modulate HIV-1 posttranscriptional expression. MBio. 2013;4:e00596-00512.

105. Hutchinson JN, Ensminger AW, Clemson CM, Lynch CR, Lawrence $J B$, Chess A. A screen for nuclear transcripts identifies two linked noncoding RNAs associated with SC35 splicing domains. BMC Genom. 2007;8:39.

106. Clemson CM, Hutchinson JN, Sara SA, Ensminger AW, Fox AH, Chess A, Lawrence JB. An architectural role for a nuclear noncoding RNA: NEAT1 RNA is essential for the structure of paraspeckles. Mol Cell. 2009;33:717-26.

107. Hirose T, Virnicchi G, Tanigawa A, Naganuma T, Li R, Kimura H, Yokoi T, Nakagawa S, Benard M, Fox AH, Pierron G. NEAT1 long noncoding RNA regulates transcription via protein sequestration within subnuclear bodies. Mol Biol Cell. 2014;25:169-83.

108. Zolotukhin AS, Michalowski D, Bear J, Smulevitch SV, Traish AM, Peng R, Patton J, Shatsky IN, Felber BK. PSF acts through the human immunodeficiency virus type $1 \mathrm{mRNA}$ instability elements to regulate virus expression. Mol Cell Biol. 2003;23:6618-30.

109. Yedavalli VS, Jeang KT. Matrin 3 is a co-factor for HIV-1 Rev in regulating post-transcriptional viral gene expression. Retrovirology. 2011;8:61.

110. Budhiraja S, Liu H, Couturier J, Malovannaya A, Qin J, Lewis DE, Rice AP. Mining the human complexome database identifies RBM14 as an XPO1-associated protein involved in HIV-1 Rev function. J Virol. 2015;89:3557-67.

111. Nguyen VT, Kiss T, Michels AA, Bensaude O. 7SK small nuclear RNA binds to and inhibits the activity of CDK9/cyclin T complexes. Nature. 2001;414:322-5.

112. Yang $\mathrm{S}$, Sun $\mathrm{Y}$, Zhang $\mathrm{H}$. The multimerization of human immunodeficiency virus type I Vif protein: a requirement for Vif function in the viral life cycle. J Biol Chem. 2001;276:4889-93. 
113. Mancebo HS, Lee G, Flygare J, Tomassini J, Luu P, Zhu Y, Peng J, Blau C, Hazuda D, Price D, Flores O. P-TEFb kinase is required for HIV Tat transcriptional activation in vivo and in vitro. Genes Dev. 1997;11:2633-44.

114. Triboulet R, Mari B, Lin YL, Chable-Bessia C, Bennasser Y, Lebrigand K, Cardinaud B, Maurin T, Barbry P, Baillat V, et al. Suppression of microRNA-silencing pathway by HIV-1 during virus replication. Science. 2007:315:1579-82.

115. Yeung ML, Bennasser Y, Myers TG, Jiang G, Benkirane M, Jeang KT. Changes in microRNA expression profiles in HIV-1-transfected human cells. Retrovirology. 2005;2:81.

116. Houzet L, Yeung ML, de Lame V, Desai D, Smith SM, Jeang KT. MicroRNA profile changes in human immunodeficiency virus type 1 (HIV-1) seropositive individuals. Retrovirology. 2008:5:118.

117. Bennasser Y, Le SY, Benkirane M, Jeang KT. Evidence that HIV-1 encodes an siRNA and a suppressor of RNA silencing. Immunity. 2005:22:607-19.

118. Chendrimada TP, Gregory RI, Kumaraswamy E, Norman J, Cooch N, Nishikura K, Shiekhattar R. TRBP recruits the Dicer complex to Ago2 for microRNA processing and gene silencing. Nature. 2005;436:740-4.

119. Hariharan M, Scaria V, Pillai B, Brahmachari SK. Targets for human encoded microRNAs in HIV genes. Biochem Biophys Res Commun. 2005;337:1214-8.

120. Ahluwalia JK, Khan SZ, Soni K, Rawat P, Gupta A, Hariharan M, Scaria V, Lalwani M, Pillai B, Mitra D, Brahmachari SK. Human cellular microRNA hsa-miR-29a interferes with viral nef protein expression and HIV-1 replication. Retrovirology. 2008;5:117.

121. Sun G, Li H, Wu X, Covarrubias M, Scherer L, Meinking K, Luk B, Chomchan P, Alluin J, Gombart AF, Rossi JJ. Interplay between HIV-1 infection and host microRNAs. Nucleic Acids Res. 2012;40:2181-96.

122. Houzet L, Klase Z, Yeung ML, Wu A, Le SY, Quinones M, Jeang KT. The extent of sequence complementarity correlates with the potency of cellular miRNA-mediated restriction of HIV-1. Nucleic Acids Res. 2012:40:11684-96.

123. Whisnant AW, Bogerd HP, Flores O, Ho P, Powers JG, Sharova N, Stevenson $\mathrm{M}$, Chen CH, Cullen BR. In-depth analysis of the interaction of HIV-1 with cellular microRNA biogenesis and effector mechanisms. MBio. 2013;4:e000193.

124. Bishop JM, Levinson WE, Quintrell N, Sullivan D, Fanshier L, Jackson J. The low molecular weight RNAs of Rous sarcoma virus. I. The 4 S RNA. Virology. 1970;42:182-95.

125. Telesnitsky A, Wolin SL. The host RNAs in retroviral particles. Viruses. 2016;8:235.

126. Huang Y, Mak J, Cao Q, Li Z, Wainberg MA, Kleiman L. Incorporation of excess wild-type and mutant tRNA(3Lys) into human immunodeficiency virus type 1. J Virol. 1994;68:7676-83.

127. Onafuwa-Nuga AA, Telesnitsky A, King SR. 7SL RNA, but not the 54-kd signal recognition particle protein, is an abundant component of both infectious HIV-1 and minimal virus-like particles. RNA. 2006;12:542-6.

128. Wang T, Tian C, Zhang W, Luo K, Sarkis PT, Yu L, Liu B, Yu Y, Yu XF. 7SL RNA mediates virion packaging of the antiviral cytidine deaminase APOBEC3G. JVirol. 2007;81:13112-24.

129. Eckwahl MJ, Arnion H, Kharytonchyk S, Zang T, Bieniasz PD, Telesnitsky A, Wolin SL. Analysis of the human immunodeficiency virus-1 RNA packageome. RNA. 2016;22:1228-38.

130. Eckwahl MJ, Sim S, Smith D, Telesnitsky A, Wolin SL. A retrovirus packages nascent host noncoding RNAs from a novel surveillance pathway. Genes Dev. 2015;29:646-57.

131. Bogerd HP, Kennedy EM, Whisnant AW, Cullen BR. Induced packaging of cellular MicroRNAs into HIV-1 virions can inhibit infectivity. MBio. 2017;8(1):e02125-16.

132. Li J, Chen C, Ma X, Geng G, Liu B, Zhang Y, Zhang S, Zhong F, Liu C, Yin Y, et al. Long noncoding RNA NRON contributes to HIV-1 latency by specifically inducing tat protein degradation. Nat Commun. 2016;7:11730.
133. Romanchikova N, Ivanova V, Scheller C, Jankevics E, Jassoy C, Serfling E. NFAT transcription factors control HIV-1 expression through a binding site downstream of TAR region. Immunobiology. 2003;208:361-5.

134. Willingham AT, Orth AP, Batalov S, Peters EC, Wen BG, Aza-Blanc P, Hogenesch JB, Schultz PG. A strategy for probing the function of noncoding RNAs finds a repressor of NFAT. Science. 2005;309:1570-3.

135. Imam H, Bano AS, Patel P, Holla P, Jameel S. The IncRNA NRON modulates HIV-1 replication in a NFAT-dependent manner and is differentially regulated by early and late viral proteins. Sci Rep. 2015;5:8639.

136. Zapata JC, Campilongo F, Barclay RA, DeMarino C, Iglesias-Ussel MD, Kashanchi F, Romerio F. The human immunodeficiency virus 1 ASP RNA promotes viral latency by recruiting the Polycomb Repressor Complex 2 and promoting nucleosome assembly. Virology. 2017;506:34-44.

137. Zhang $Y$, Yin $Y$, Zhang S, Luo H, Zhang H. HIV-1 infection-induced suppression of the Let-7i/IL-2 axis contributes to $C D 4^{+} \mathrm{T}$ cell death. Sci Rep. 2016;6:25341.

138. Rosewick N, Momont M, Durkin K, Takeda H, Caiment F, Cleuter Y, Vernin C, Mortreux F, Wattel E, Burny A, et al. Deep sequencing reveals abundant noncanonical retroviral microRNAs in B-cell leukemia/lymphoma. Proc Natl Acad Sci USA. 2013;110:2306-11.

139. Deeks SG. HIV: shock and kill. Nature. 2012;487:439-40.

140. Manninen A, Renkema GH, Saksela K. Synergistic activation of NFAT by HIV-1 nef and the Ras/MAPK pathway. J Biol Chem. 2000;275:16513-7.

141. Chun TW, Engel D, Mizell SB, Hallahan CW, Fischette M, Park S, Davey RT Jr, Dybul M, Kovacs JA, Metcalf JA, et al. Effect of interleukin-2 on the pool of latently infected, resting $\mathrm{CD}^{+} \mathrm{T}$ cells in HIV-1-infected patients receiving highly active anti-retroviral therapy. Nat Med. 1999;5:651-5.

142. Kulkosky J, Culnan DM, Roman J, Dornadula G, Schnell M, Boyd MR, Pomerantz RJ. Prostratin: activation of latent HIV-1 expression suggests a potential inductive adjuvant therapy for HAART. Blood. 2001;98:3006-15.

143. Ylisastigui L, Archin NM, Lehrman G, Bosch RJ, Margolis DM. Coaxing HIV-1 from resting CD4T cells: histone deacetylase inhibition allows latent viral expression. AIDS. 2004;18:1101-8.

144. Archin NM, Espeseth A, Parker D, Cheema M, Hazuda D, Margolis DM. Expression of latent HIV induced by the potent HDAC inhibitor suberoylanilide hydroxamic acid. AIDS Res Hum Retrovir. 2009;25:207-12.

145. Contreras X, Schweneker M, Chen CS, McCune JM, Deeks SG, Martin J, Peterlin BM. Suberoylanilide hydroxamic acid reactivates HIV from latently infected cells. J Biol Chem. 2009;284:6782-9.

146. Zhang H. Reversal of HIV-1 latency with anti-microRNA inhibitors. Int J Biochem Cell Biol. 2009:41:451-4.

147. Bandaranayake RM, Kolli M, King NM, Nalivaika EA, Heroux A, Kakizawa J, Sugiura W, Schiffer CA. The effect of clade-specific sequence polymorphisms on HIV-1 protease activity and inhibitor resistance pathways. J Virol. 2010;84:9995-10003.

148. Yang JH, Li JH, Shao P, Zhou H, Chen YQ, Qu LH. starBase: a database for exploring microRNA-mRNA interaction maps from Argonaute CLIP-Seq and Degradome-Seq data. Nucleic Acids Res. 2011;39:D202-9.

149. van Dijk EL, Auger H, Jaszczyszyn $Y$, Thermes $C$. Ten years of next-generation sequencing technology. Trends Genet. 2014;30:418-26.

\section{Submit your next manuscript to BioMed Central and we will help you at every step:}

- We accept pre-submission inquiries

- Our selector tool helps you to find the most relevant journal

- We provide round the clock customer support

- Convenient online submission

- Thorough peer review

- Inclusion in PubMed and all major indexing services

- Maximum visibility for your research

Submit your manuscript at www.biomedcentral.com/submit 